„Analecta Cracoviensia” 48 (2016), s. 125-140

DOI: http://dx.doi.org/10.15633/acr.2020

Krzysztof Niewiadomski ofmcap

Wyższe Seminarium Duchowne Braci Mniejszych Kapucynów, Kraków

\title{
Błogosławiony Jan Duns Szkot \\ o możliwości przyjęcia komunii świętej \\ w stanie grzechu śmiertelnego. \\ Analiza w kontekście współczesnych dyskusji teologiczno-dyscyplinarnych
}

Szerszym tłem debaty nad przyjmowaniem komunii świętej przez osoby żyjące w związkach niesakramentalnych jest ryzyko dopuszczenia do sakramentu osób będących w stanie grzechu śmiertelnego. Podejmując ten temat, warto odwołać się nie tylko do orzeczeń Magisterium Kościoła', ale także do szerszej tradycji, m.in. do refleksji teologicznej. Istnieje bowiem w Kościele pewien

1 Przykłady nauczania magisterialnego z ostatniego czasu na temat przyjmowania komunii świętej: Jan Paweł II, adhort. apost. Familiaris consortio (22 listopada 1981) [dalej: FC], 84: „Kościół jednak na nowo potwierdza swoją praktykę, opartą na Piśmie Świętym, niedopuszczania do komunii eucharystycznej rozwiedzionych, którzy zawarli ponowny związek małżeński. Nie mogą być dopuszczeni do komunii świętej od chwili, gdy ich stan i sposób życia obiektywnie zaprzeczają tej więzi miłości między Chrystusem i Kościołem, którą wyraża i urzeczywistnia Eucharystia. Jest poza tym inny szczególny motyw duszpasterski: dopuszczenie ich do Eucharystii wprowadzałoby wiernych w błąd lub powodowałoby zamęt co do nauki Kościoła o nierozerwalności małżeństwa”; Katechizm Kościoła katolickiego, Poznań 2002 [dalej: ккK], 1650: „Jeśli rozwiedzeni zawarli cywilnie drugi związek małżeński, znajdują się w sytuacji, która obiektywnie wykracza przeciw prawu Bożemu. Dlatego nie mogą oni przystępować do komunii eucharystycznej tak długo, jak długo trwa ta sytuacja. Z tego samego powodu nie mogą oni pełnić pewnych funkcji kościelnych. Pojednanie przez sakrament pokuty może być udzielane tylko tym, którzy żałują, że złamali znak Przymierza i wierności Chrystusowi, i zobowiązują się żyć w całkowitej wstrzemięźliwości”. 
rodzaj nauczania - czyli nauczanie teologów - które, pozostając w łączności $\mathrm{z}$ nauczaniem Magisterium, jednak nim nie jest ${ }^{2}$. Argumentacja teologów z różnych epok historii Kościoła jest często bardziej obszerna, a analiza bardziej wnikliwa, niż ta, którą mogą zawierać dokumenty magisterialne, charakteryzujące się pewną zwięzłością. Wśród teologów szczególne znaczenie mają ci, którzy ze względu na swój wybitny wkład w rozwój rozumienia Objawienia Bożego zostali uhonorowany tytułem doktora Kościoła. Dodatkowo świętość ich życia potwierdzona przez Kościół wskazuje na ich otwartość na działanie Ducha Świętego w badaniach teologicznych ${ }^{3}$.

Bez wątpienia jednym z bardziej oryginalnych teologów jest bł. Jan Duns Szkot (ok. 1265-1308), franciszkański uczony scholastyczny, który ze względu na gruntowność i precyzję swoich wywodów otrzymał tytuł doktora subtelnego (doctor subtilis). Wnikliwość jego dowodzenia i głęboka intuicja teologiczna sprawiły, że w swoich tezach wyprzedził on poglądy własnej epoki, np. broniąc przywileju Niepokalanego Poczęcia Matki Bożej, wbrew opinii takich ówczesnych autorytetów jak św. Tomasz z Akwinu czy św. Bonawentura. W swoim najważniejszym dziele - Ordiantio, doctor subtilis, zabrał głos także w kwestii przyjmowania komunii świętej w stanie grzechu śmiertelnego ${ }^{4}$.

\section{Ordinatio bł. Jana Dunsa Szkota o przyjmowaniu komunii świętej}

Zagadnienie przyjmowania komunii świętej zawarte jest w księdze czwartej Ordinatio, poświęconej sakramentom, paralelnej do księgi czwartej Sentencji Piotra Lombarda, komentowanych przez Dunsa Szkota w jego dziele. $\mathrm{W}$ distinctio numer dziewięć doctor subtilis bada tylko jedną kwestię, mianowicie, czy człowiek będący w grzechu śmiertelnym grzeszyłby śmiertelnie

\footnotetext{
2 Por. Międzynarodowa Komisja Teologiczna, Teologia dzisiaj. Perspektywy, zasady i kryteria, Kraków 2012 [dalej: TD], 39.

Kongregacja Nauki Wiary, Instrukcja o powołaniu teologa w Kościele Donum veritatis, [w:] W trosce o petnię wiary. Dokumenty Kongregacji Nauki Wiary, t. 1, red. J. Królikowski, Z. Zimowski, Tarnów 1995 [dalej: Dv], 8: „Ponieważ przedmiotem teologii jest Prawda, żywy Bóg i Jego objawiający się w Jezusie Chrystusie plan zbawienia, teolog - z racji swojego powołania - musi żyć intensywną wiarą i zawsze łączyć badania naukowe z modlitwą. Pozwoli mu to wyrobić sobie większą wrażliwość na nadprzyrodzony zmyst wiary, od którego wszystko zależy i w którym znajdzie niezawodną regułę kierującą jego refleksją oraz kryterium oceny poprawności jej wyników”.

4 Autor artykułu przytacza myśl Szkota na podstawie tekstu łacińskiego. Nie jest to jednak dosłowne tłumaczenie.
} 
przyjmowaniem sakramentu Eucharystii (Utrum existens in peccato mortali pecet mortaliter percipiendo Sacramentum Eucharistiae).

Posługując się metodą scholastyczną, autor podaje najpierw argumenty, $\mathrm{z}$ których mogłaby wynikać odpowiedź negatywna na pytanie zawarte $\mathrm{w}$ tytule kwestii. Są one następujące: nikt nie grzeszy czynieniem tego, do czego jest zobowiązany, tymczasem każdy zawsze, niezależnie od tego, czy byłby w stanie grzechu ciężkiego, jest zobowiązany komunikować. Formułując to zobowiązanie, Duns Szkot powołuje się na tzw. Extravagantium ${ }^{5}$, obowiązujący w jego czasach zbiór kanonów prawa kościelnego, a dokładniej na zawartą tam konstytucję Omnis utriusque sexus, mówiącą, że każdy chrześcijanin powinien raz w roku komunikować. ${ }^{6}$ Dodaje do tego inny argument, również oparty na jednym z ówczesnych zbiorów praw, Dekrecie Gracjana. Powołuje się on dokładnie na ustęp, w którym jest powiedziane, że kapłan, który konsekrował, powinien przyjąć komunię̧, a przecież możliwe jest, że wtedy byłby w grzechu ciężkim albo w międzyczasie wpadłby w grzech ciężki i wtedy nie musiałby się spowiadać, bowiem wystarczy to uczynić tylko raz w roku'. Podobnie nikt nie jest zobowiązany wyznawać grzechów częściej niż raz w roku, jak jest jasne z Extravagantium rozdział: Omnis utriusque sexus, więc każdy

5 Pełny tytuł cytowanego dzieła to: Decretalium Gregorii papae IX. Ten zbiór dokumentów został zredagowany przez Raymunda de Pennaforte, znany był najpierw jako Raymundi de Pennaforte Extravagantium Decretalium libri $v$. Przytaczany tekst kanonu zawarty jest w księdze 5, titulus 38 : De poenitentiis et remissionibus, cap. 12.

6 Por. Jan Duns Szkot, Ordinatio, Civitas Vaticana 2010, lb. Iv, dist. 9, q. 1, 5 (Opera omnia, vol. 12). Omnis utriusque sexus to konstytucja 21 Soboru Laterańskiego Iv. Por. Dokumenty soborów powszechnych, t. 2, red. A. Baron, H. Pietras, Kraków 2007, s. 258-261.

7 Dekret Gratiana, pars 3: De Consecratione, dist. 2, cap. 11. Rozdział ten nosi tytuł: Quisque sacerdos, quociens missam celebrat, tociens sacram communionem percipiat. Gratian cytuje w nim dwunasty synod w Toledo (681), pars 4, cap. 5: „Relatum est nobis, quosdam de sacerdotibus non tot vicibus communionis sanctae gratiam sumere, quot sacrificia in uno die videntur offerre; sed si in uno die plurima deo offerant sacrificia, in omnibus se oblationibus a communione suspendant, et in sola tantum extrema sacrificii oblatione communionis sanctae gratiam sumunt, quasi non sit toties illi vero et singulari sacrificio participandum, quoties corporis et sanguinis Domini nostri Iesu Christi inmolatio facta constiterit. Nam ecce Apostolus dicit: Nonne qui edunt hostias participes sunt altaris? Certum est, quod hi, qui sacrificantes non edunt, rei sunt dominici sacramenti. Quicumque ergo sacerdotum deinceps divino altario sacrificium oblaturus accesserit, et se a communione suspenderit, ab ipsa, qua se indecenter privavit, gratia communionis anno uno repulsum se noverit. Nam quale erit sacrificium, cui nec ipse sacrificans particeps esse cognoscitur? Ergo modis omnibus tenendum est, ut, quocienscumque sacrificans corpus et sanguinem Iesu Christi Domini nostri in altario inmolat, toties perceptionis corporis et sanguinis Christi participem se praebeat".

8 Por. Jan Duns Szkot, Ordinatio, dz. cyt., 5. 
może wykonywać stosowne akty, nawet jeżeli nie wyznawałby często grzechów. Dlatego kapłan może często celebrować bez powtórnej spowiedzi, obojętnie, ile by zgrzeszył. Nie wydaje się bowiem z powodu wspomnianego przykazania, że jemu nie wystarczałoby dla zbawienia wspólne wyznanie, jak i innym chrześcijanom, gdy nie wydaje się zobowiązany specjalnym prawem

Jako argumenty przeciwne powyższym doctor subtilis przytacza fragmenty z Pisma św. i tradycji patrystycznej. Są to Pierwszy List do Koryntian: „Kto bowiem spożywa i pije nie zważając na Ciało Pańskie, wyrok sobie spożywa i pije" (1 Kor 11, 29). Takim jest według Szkota ten, który duchowo nie jest członkiem Chrystusa i przyjmuje Eucharystię, której spożycie oznacza duchowe włączenie w Chrystusa. Ponadto św. Augustyn w homilii do Ewangelii według św. Jana, wspominając o złym kapłanie, mówi: „tak wielki Sakrament dla sądu przyjmuje"10.

Przystępując do rozwiązania problemu, Duns Szkot najpierw dokonuje podziału, który będzie przydatny w dalszych rozważaniach. Zauważa on, że bycie w grzechu śmiertelnym można rozumieć na trzy sposoby: po pierwsze w akcie, mianowicie wtedy, gdy ktoś grzeszy ciężko grzechem wewnętrznym lub zewnętrznym; po drugie - że po grzechu ciężkim przeszłym, o którym nie pamięta, nie pokutował ani nie pokutuje; po trzecie - że chociaż z tej grzesznej przeszłości pokutował albo pokutuje, jednak nie wyznał grzechu ani nie został oczyszczony w Kościele ${ }^{11}$.

O pierwszym przypadku Duns Szkot mówi, że człowiek taki grzeszy ciężko, przyjmując komunię, ponieważ bezwzględnie spożywa ją niegodnie ${ }^{12}$. O drugim twierdzi, że jeśli zaniedbanie, przez które nie wspomina grzechu, jest zamierzone lub poważne, nie jest usprawiedliwiony z grzechu niegodnego

9 Por. tamże, 6.

10 Por. tamże, 7-8. Szkot cytuje tu św. Augustyna, który pisze: „Denique iam exponit quomodo id fiat quod loquitur, et quid sit manducare corpus eius, et sanguinem bibere. Qui manducat carnem meam, et bibit meum sanguinem, in me manet, et ego in illo. Hoc est ergo manducare illam escam, et illum bibere potum, in Christo manere, et illum manentem in se habere. Ac per hoc qui non manet in Christo, et in quo non manet Christus, procul dubio nec manducat $\mathrm{z}$ carnem eius, nec bibit eius sanguinem, sed magis tantae rei Sacramentum ad iudicium sibi manducat et bibit, quia immundus praesumpsit ad Christi accedere Sacramenta, quae aliquis non digne sumit, nisi qui mundus est; de quibus dicitur: Beati mundo corde quoniam ipsi Deum videbunt". W polskim wydaniu: Augustyn, Homilia 26, 18, [w:] Homilie na Ewangelie i Pierwszy List św. Jana, t. 1, przeł. W. Szołdrski, W. Kania, Warszawa 1977, s. 378.

${ }^{11}$ Por. Jan Duns Szkot, Ordinatio, dz. cyt., 9.

${ }_{12}$ Por. tamże, 10. 
komunikowania, chociaż mniej grzeszy niż pierwszy ${ }^{13}$. Dla Dunsa Szkota jest to oczywiste na podstawie Pierwszego Listu do Koryntian, komunikujący ma bowiem siebie badać, według pilności możliwej dla ludzkiej ułomności, zanim by przyjmował Najświętszy Sakrament (1 Kor 11, 28) ${ }^{14}$.

Jeśli zaś nie byłoby poważnego zaniedbania, ponieważ na przykład ktoś poprzedził komunię wystarczającym badaniem i żaden grzech nie przyszedłby mu do głowy, który nie byłby albo nie jest żałowany i wyspowiadany wcześniej, nie grzeszy komunikowaniem, chociaż przypadkiem coś byłoby ukryte albo zapomniane ${ }^{15}$. To jest dowiedzione. Po pierwsze bowiem, jeśli umarłby po takim badaniu skruszony i wyspowiadany, zbawiłby się, badanie zaś nie jest wymagane bardziej do komunikowania niż do bezpiecznej śmierci. Po drugie, ponieważ w przeciwnym razie każdy siebie wystawiałby na niebezpieczne komunikowanie, bowiem psalmista mówi: „kto widzi swoje błędy” (Ps 19, 13), i Eklezjastes: „nie wie człowiek, czy miłości czy nienawiści jest godzien" (Koh 9, 1), więc jeśli byłoby konieczne komunikującemu wiedzieć' ${ }^{16}$, czy jest w miłości (esse in caritate), każdy komunikowaniem wystawiałby się na niebezpieczeństwo, nie wiedząc, czy w tym akcie zgrzeszyłby ${ }^{17}$. Po trzecie jest to dowiedzione, bowiem wtedy nie byłby to sakrament wędrowca, jako że taka pewność nie jest odpowiednia pielgrzymowi do Królestwa Bożego (co do bycia w miłości). Ze względu na to Duns Szkot twierdzi, że po pilnym badaniu czynów w sposób możliwy dla ludzkiej ułomności, i po uprzednim żalu i spowiedzi, kto wówczas komunikowałby, nie grzeszy, a nawet jeśli jakieś inne grzechy pozostałyby w ukryciu, przez ten sakrament także byłyby odpuszczone ${ }^{18}$.

O trzecim sposobie trwania w grzechu (gdy jego sprawca nie został jeszcze oczyszczony spowiedzią) bł. Jan Duns Szkot uczy, że jeśli zdarzyłaby się sposobność, ma on najpierw wyspowiadać się, zanim by komunikował. Nie tylko bowiem powinien być pojednany z Bogiem, lecz także z Kościołem, w tym celu, aby godnie przyjąć sakrament kościelnej jedności. Jeśli zaś nie zdarzyłaby się sposobność wyznania, gdy może bez zgorszenia unikać komunikowania,

13 Por. tamże, 11.

14 Por. tamże, 11.

15 Por. tamże, 12.

16 Użyte tu słowo scire oznacza dla Dunsa Szkota wiedzę pewną, opartą na ścisłym rozumowaniu dedukcyjnym.

17 Por. Jan Duns Szkot, Ordinatio, dz. cyt., 13.

18 Por. tamże, 13-14. 
jest zobowiązany nie komunikować, lecz czekać spowiedzi dla tej racji, która jest teraz przytaczana ${ }^{19}$.

Jeśli rzeczywiście następuje zgorszenie, gdy natychmiast nie komunikowałby, mianowicie jeśli jest ubrany $\left(\right.$ indutus ${ }^{20}$ ) i gdy jest ubrany pojawia się mu świadomość grzechu ciężkiego, z którego nie był wyspowiadany, a nie ma łatwo dostępnego właściwego spowiednika, wtedy z żalem i wolą wyznania w odpowiednim czasie może celebrować, aby uniknąć zgorszenia ${ }^{21}$. Podobnie można powiedzieć o innych mających komunikować, którzy nie celebrują, bo przecież jest zwyczaj w każdym zakonie i Kościele, aby wszyscy niekapłani komunikowali w podobnym przypadku, tj. jeśli wtedy, gdy mają przyjąć komunię, nie ma odpowiedniego spowiednika, mogą wtedy niewyspowiadani komunikować ${ }^{22}$.

I nie musi być powiedziane, że grzeszy ciężko albo przekracza przykazanie, gdy ktoś unika zgorszenia, bowiem żadne przykazanie nie wyklucza go od tego aktu w tym przypadku, gdyż odłożenie aktu spowiedzi (dilatio confessionis in actu), która teraz byłaby w zamiarze, nie wyklucza, ażeby był członkiem Kościoła walczącego, zdolnym do aktów, w których członkowie Kościoła jednoczą się, i ma unikać zgorszenia bliźniego ${ }^{23}$.

Odnośnie zaś do grzechu powszedniego nie można być niepewnym, że z niego nie ma konieczności pokuty. Jednak opinia De ecclesiasticis dogmatibus, która jest przytaczana w dystynkcji dwunastej, zdaje się czynić wzmiankę o grzechu powszednim, mówi bowiem: „Może ktoś być dręczony grzechem, jeśli na przyszłość nie ma woli grzeszenia, i zadośćczyniłby łzami i modlitwami, zbliżałby się pewny, i to mówię o tym, którego ciężkie grzechy nie obciążają (quem mortalia peccata non gravant)"24. Przeto wydaje się, że nie może ktoś pewny przystępować, tylko ten, kto byłby bez woli grzechu powszedniego i przeszłość zadośćuczyniłby łzami i modlitwami ${ }^{25}$. Duns Szkot odpowiada, że może być to rozumiane o grzechu śmiertelnym, nie tym, który teraz jest

19 Por. tamże, 15-16.

${ }^{20}$ Ubrany do sprawowani liturgii, przyp. K. N.

${ }^{21}$ Por. tamże, 17.

22 Por. tamże, 18.

${ }_{23}$ Por. tamże, 18.

${ }^{24}$ Duns Szkot powołuje się tu na Piotra Lombarda, który z kolei cytuje Gennadiusa Scholasticusa, De Ecclesiasticis dogmatibus, cap. 53. Por. Petrus Lombardus, Libri IV sententiarum, vol. 2, Florentia 1916, lb. 4, dist. 12, cap. 4.

25 Por. Jan Duns Szkot, Ordinatio, dz. cyt., 19-20. 
ani w przeszłości, bez całej pokuty, lecz o wyznanym, jeśli byłby dręczony, że niekompletnie zadośćuczynił ${ }^{26}$.

$\mathrm{Na}$ zakończenie, w odpowiedzi na argumenty przeciwne udowadnianej tezie, podane na początku rozważania, doctor subtilis stwierdza: do pierwszego argumentu (nr 5), że czyniący z obowiązku to, co powinien, nie grzeszy. Do przesłanki mniejszej, że nikt nie powinien komunikować w grzechu cięż$\mathrm{kim}^{27}$. Do pierwszego dowodu mówi, że jak jest się zobowiązanym raz w roku komunikować, tak jest się zobowiązanym starać się przez pokutę, aby nie być w grzechu śmiertelnym, co także przypomina Extravagantium w cytowanym rozdziale ${ }^{28}$.

Do drugiego dowodu Szkot dodaje, że kapłan, zanim przystąpiłby do konsekracji, ma starać się być bez grzechu śmiertelnego. Jeśli zaś stałoby się tak, że po konsekracji, jednak przed komunią, pojawiłoby się mu wspomnienie grzechu śmiertelnego kiedyś popełnionego, którego nie przewyższyła pokuta zewnętrzna lub wewnętrzna, ma wtedy odbyć pokutę wewnętrzną, zanim przyjąłby komunię, i odłożyć pokutę zewnętrzną do momentu, gdy zajdzie możliwość wyznania ${ }^{29}$.

Co do argumentu drugiego (nr 6) Duns Szkot stwierdza, że przepis soboru o spowiedzi raz w roku określa minimalną częstotliwość, z jaką wierni mają przystępować do sakramentu pojednania. W wielu przypadkach są oni jednak zobowiązani do pokuty zewnętrznej, jak ciężko chory, o którym powątpiewa się (czy przeżyje) albo podejmujący działanie, w którym prawdopodobne jest, według ludzkiego sądu, że wystawia się na niebezpieczeństwo śmierci, na przykład w śmiertelnej walce. Podobnie również specjalne prawo obowiązuje kapłana przed wykonaniem aktu komunikowania do pokuty zewnętrznej ${ }^{30}$. I jeśli kto pyta, jakie prawo, Duns Szkot stwierdza, że chodzi o prawo apostoła, które jest ustanowione w Pierwszym Liście do Koryntian, „aby człowiek badał siebie samego" (1 Kor 11, 28) $)^{31}$.

\footnotetext{
26 Por. tamże, 21.

27 Por. tamże, 22-23.

28 Por. tamże, 24.

29 Por. tamże, 25.

30 Por. tamże, 26.

${ }_{31}$ Por. tamże, 27.
} 


\section{Argumentacja bł. Jana Dunsa Szkota wobec współczesnych tendencji liberalizacji dyscypliny sakramentalnej}

Dokonując szczegółowej analizy różnych przypadków, bł. Jan Duns Szkot nie dopuszcza możliwości przyjmowania komunii świętej przez osobę trwającą w grzechu śmiertelnym. Franciszkański teolog powołuje się tu na Pismo Święte i tradycję patrystyczną - Pierwszy List do Koryntian i Homilię dwudziestą szóstą św. Augustyna. Mając sprawę za oczywistą, zamyka całe rozważanie na ten temat $\mathrm{w}$ jednym zdaniu, uznając taki akt komunikowania za kolejny grzech śmiertelny ${ }^{32}$. Jest to znamienne, ponieważ zwykle rozwija on szerzej swoje refleksje, pragnąc jak najdokładniej rozważyć wszystkie argumenty. Można śmiało powiedzieć, że do tradycji biblijnej i patrystycznej dołącza się nauczanie scholastyków, zabraniające przyjmowania komunii świętej osobie niebędącej w stanie łaski uświęcającej ${ }^{33}$. Jednocześnie doctor subtilis nie pozwala na wątpliwości co do grzechu powszedniego, podejmując polemikę z interpretacjami tekstów teologicznych, mogących budzić skrupuły w tej materii. Grzech powszedni nie jest przeszkodą w przyjmowaniu Eucharystii, stąd nie musi dokonywać się pokuta sakramentalna przed każdym takim aktem ${ }^{34}$.

Niepewność co do istnienia grzechu śmiertelnego, czy jego zapomnienie, stawia człowieka w innej sytuacji. Błogosławiony Jan Duns Szkot kładzie tu duży nacisk na badanie swojego sumienia, jednocześnie domagając się szacunku dla jego osądu. Bez możliwości oparcia się na sądzie swojego sumienia człowiek nie byłby zdolny do bezpiecznego przyjęcia komunii. Żadna nadprzyrodzona pewność nie jest bowiem możliwa dla niego w obecnym stanie bytowania. W ujęciu franciszkańskiego scholastyka daleko jednak refleksji nad swoim postępowaniem do współczesnych koncepcji tzw. twórczego sumienia. Jest to sumienie cały czas ograniczone prawdą, szukające obiektywnej pewności co do zaistnienia grzechu i tego, co jest tym grzechem ${ }^{35}$.

W swojej analizie doctor subtilis znajduje jeden wypadek, w którym dopuszcza możliwość komunii po popełnieniu grzechu śmiertelnego, bez uprzedniej

${ }^{32}$ O pierwszym przypadku Duns Szkot mówi, że człowiek taki grzeszy ciężko, przyjmując komunię, ponieważ bezwzględnie spożywa ją niegodnie, por. tamże, 11.

33 Por. także nauczanie św. Tomasza z Akwinu na ten temat: Tomasz z Akwinu, Suma teologiczna. Eucharystia, t. 28, przeł. S. Piotrowicz, Londyn 1974, III, q. 79, a. 3.

34 Por. Jan Duns Szkot, Ordinatio, dz. cyt., 20-21.

35 Por. Jan Paweł II, enc. Veritatis splendor (6 sierpnia 1993), 54-64. 
spowiedzi. Jak widać, jego rozważania nie mają charakteru fundamentalistycznego, nacechowanego emocjonalizmem czy związanego z jakimikolwiek uprzedzeniami. Są rzeczową, rozumową refleksją, uwzględniającą złożoność ludzkiej rzeczywistości. Mianowicie, dopuszcza on możliwość przyjęcia komunii świętej w wypadku niemożliwości wyznania grzechu, w celu uniknięcia zgorszenia, kładąc jednak wtedy nacisk na pokutę wewnętrzną, a więc nawrócenie, i pragnienie wyznania grzechu przy najbliższej okazji. Nie zwalnia więc grzesznika ani z obowiązku zmiany postępowania, ani ze spowiedzi, jedynie pozwala w nadzwyczajnej sytuacji odłożyć ostatni z wymienionych aktów penitenta. Argumentem jest tu chęć uniknięcia zgorszenia. Zgorszenie bowiem jest „postawą lub zachowaniem, które prowadzi drugiego człowieka do popełnienia zła" ${ }^{36}$, czego miłość Boga i bliźniego pragnie za wszelką cenę uniknąć. W opisywanej sytuacji istnieje taka możliwość, zarówno uniknięcia zgorszenia, jak i przyjęcia komunii bez zaciągnięcia dodatkowej winy. Albowiem postawa pokuty wewnętrznej, żal doskonały, także może zaowocować odpuszczeniem grzechu przez Boga. Wymagane jest jednoczesne postanowienie spowiedzi przy najbliższej okazji, jeśli nie jest to możliwe w danej chwili, co oznacza pragnienie pełnego pojednania się z Kościołem, czyli niepoprzestanie na samej tylko prywatnej pokucie przed Bogiem ${ }^{37}$.

Pozwolenie na komunię świętą, motywowane pragnieniem uniknięcia zgorszenia, dotyczy w nauczaniu Szkota także osób niebędących kapłanami ${ }^{38}$. Opisuje on jednak sytuację grzechu, która nie jest stała. Zakłada się, że taka osoba po pewnym czasie może wyspowiadać się i otrzymać rozgrzeszenie. Jeśli $\mathrm{w}$ dopuszczeniu do komunii bierze się pod uwagę argument groźby zgorszenia, to takiego człowieka nie może dotyczyć grzech publiczny, wtedy bowiem następuje większe zgorszenie z przyjęcia komunii świętej niż z jej opuszczenia. Publiczny akt komunii sugerowałby wtedy, że Kościół nie uznaje już pewnych uczynków za ciężkie przewinienia albo że bagatelizuje grzech.

To powyższe rozważanie nad wagą wewnętrznych aktów penitenta zachęca do refleksji nad przesadnym dowartościowaniem w świadomości niektórych

36 KKK 2284.

37 Kodeks prawa kanonicznego, Poznań 1984 [dalej: KPK], kan. 916: „Kto ma świadomość grzechu ciężkiego, nie powinien bez sakramentalnej spowiedzi odprawiać Mszy świętej ani przyjmować komunii świętej, chyba że istnieje poważna racja i nie ma sposobności wyspowiadania się. W takim jednak wypadku ma pamiętać o tym, że jest obowiązany wzbudzić akt żalu doskonałego, który zawiera w sobie zamiar wyspowiadania się jak najszybciej”.

${ }^{38}$ Por. Jan Duns Szkot, Ordinatio, dz. cyt., 18. 
wiernych skuteczności spowiedzi ex opere operato. Zjawisko to jest związane z legalistycznym i urzeczowiającym podejściem do życia sakramentalnego ${ }^{39}$. Samo wyznanie grzechu, bez żalu i postanowienia poprawy, miałoby uprawniać w mniemaniu przystępującego do spowiedzi także do przyjmowania komunii świętej. Tymczasem wyznanie win to tylko jeden $\mathrm{z}$ wymaganych aktów penitenta, niestety przy magicznym traktowaniu formuły rozgrzeszenia kładzie się nacisk tylko na sam obrzęd sakramentu. W związku z taką postawą także samemu wyznaniu grozi powierzchowność, to, że nie zobrazuje ono już faktycznego stanu duszy wiernego przez braki w określeniu gatunku grzechu czy jego ilości. Na ten błąd zwrócił uwagę sobór trydencki ${ }^{40}$. Takie podejście może owocować także chęcią oszukania spowiednika, aby za wszelką cenę otrzymać rozgrzeszenie, a nawet szukania innego kapłana w wypadku odmówienia rozgrzeszenia, takiego, który nie zwróciłby należytej uwagi na wszystkie wymagane akty penitenta.

Przy okazji powyższych rozważań pastoralnych warto zwrócić uwagę na jeszcze jeden aspekt praktyki sakramentalnej Kościoła. Refleksje Dunsa Szkota są świadectwem recepcji soboru laterańskiego IV (1215) w bezpośredniej jego bliskości (Ordinatio zostało zakończone ok. 1304 roku $^{41}$ ). Chodzi mianowicie o orzeczenie soborowe o obowiązku spowiedzi co najmniej raz w roku. Doctor subtilis przypomina, że chodzi w nim o minimum, a nie o normę $e^{42}$. Należy dziś wyraźnie to zaznaczać w nauczaniu o sakramencie pojednania, minimalizm przyczynia się bowiem do pogłębienia formalizmu religijnego, którego efektem może być także domaganie się komunii w stanie grzechu śmiertelnego.

Duns Szkot wskazuje również na wymiar eschatologiczny życia moralnego ${ }^{43}$. Badanie stanu sumienia jest konieczne dla życia wiecznego. Podobnie zresztą przyjmowanie komunii świętej ma człowieka do tego stanu przygotować, uświęcić. Taka perspektywa właściwie ukierunkowuje życie religijne, akty pobożności nie mają bowiem na celu osiągnięcia doczesnego dobrostanu, poczucia bycia zaakceptowanym, przygarniętym przez Kościół, ale zbawienie wieczne.

39 Por. E. Kaczyński, Prawda, dobro, sumienie. Z zagadnień teologii moralnej, Warszawa 2007, S. 48 .

40 Por. Sobór Trydencki, Nauka o świętych sakramentach pokuty i ostatniego namaszczenia, r. 5, [w:] Dokumenty soborów powszechnych, t. 4, red. A. Baron, H. Pietras, Kraków 2004, s. 491-493.

${ }^{4}$ Por. T. Williams, Introduction. The life and works of John Duns the Scot, [w:] The Cambridge companion to Duns Scotus, ed. T. Williams, Cambridge 2003, s. 9.

42 Por. Jan Duns Szkot, Ordinatio, dz. cyt., 25.

43 Por, tamże, 14. 
Duns Szkot dopuszcza odroczenie pojednania sakramentalnego w wypadku niebezpieczeństwa zgorszenia, jednak przypomina, że trwanie w grzechu uniemożliwia przyjęcie komunii, musi nastąpić nawrócenie człowieka. Natomiast współcześni teologowie proponujący dopuszczenie do komunii osób w stanie grzechu ciężkiego wymagają nie tyle zerwania ze złem, co zaistnienia pewnej sytuacji, która miałaby być usprawiedliwieniem dla grzechu. Sytuacje te opisuje List Kongregacji Nauki Wiary na temat przyjmowania komunii świętej przez wiernych rozwiedzionych żyjących w nowych związkach. Te rozwiązania duszpasterskie byłyby wyrazem tolerancji i życzliwości oraz chęci sprawiedliwego potraktowania rozwiedzionych żyjących w nowych związ$\mathrm{kach}^{44}$. Pod pozorem tolerancji może jednak kryć się lęk przed stawianiem wymagań, ponieważ zawsze grożą one napięciem we wzajemnych relacjach. Ze względu na krzywdę opuszczenia przez współmałżonka przyjęłoby się, że osoba ma prawo do grzesznego pożycia pozamałżeńskiego, jako sprawiedliwej rekompensaty. Prawo zaś do komunikowania byłoby tego ostatecznym usankcjonowaniem. Tymczasem grzech niegodnego przyjęcia komunii będzie wtedy dodatkowym obciążeniem moralnym, a nie rekompensatą czy uzdrowieniem życia duchowego.

Bóg powierzył Kościołowi misję odpuszczania grzechów tylko w konkretnych sytuacjach, nie rozciągając jej na te wypadki, które wymagają Jego szczególnego miłosierdzia. Nie można wymagać skuteczności ex opere operato sakramentów, nie spełniając wymagań koniecznych dla otrzymania łaski sakramentalnej. Należy jednak ufać w miłosierdzie Boże, do tej ufności zachęca także Magisterium Kościoła. Jak pisze Jan Paweł II, pozbawienie kogoś komunii świętej nie oznacza jego potępienia:

Razem z Synodem wzywam gorąco pasterzy i całą wspólnotę wiernych do okazania pomocy rozwiedzionym, do podejmowania z troskliwą miłością starań o to, by nie czuli się oni odłączeni od Kościoła, skoro mogą, owszem, jako ochrzczeni, powinni uczestniczyć w jego życiu. Niech będą zachęcani do słuchania Słowa Bożego, do uczęszczania na Mszę świętą, do wytrwania w modlitwie, do pomnażania dzieł miłości oraz inicjatyw wspólnoty na rzecz sprawiedliwości, do wychowywania dzieci w wierze chrześcijańskiej, do pielęgnowania ducha i czynów pokutnych, ażeby w ten sposób z dnia na dzień wypraszali sobie u Boga łaskę.

${ }_{44}$ Por. Kongregacja Nauki Wiary, List do biskupów Kościoła katolickiego na temat przyjmowania komunii św. przez wiernych rozwiedzionych żyjących w nowych związkach (14 września 1994), „L'Osservatore Romano” (wyd. pol.) 163 (1994) nr 11, s. 3. 
Niech Kościół modli się za nich, niech im dodaje odwagi, niech okaże się miłosierną matką, podtrzymując ich $\mathrm{w}$ wierze i nadziei ${ }^{45}$.

Budzenie ufności w Boże miłosierdzie, zachęta do aktów pobożności i pokuty, troska duszpasterska stanowią właściwe postawy wobec osób żyjących w związkach niesakramentalnych, aby nie czuły się one odrzucone przez Kościół. Zapewnienie im takiego poczucia nie jest natomiast funkcją komunii świętej. Droga do niej nie jest przecież nigdy na zawsze zamknięta. Pisze Jan Paweł II:

Pojednanie w sakramencie pokuty - które otworzyłoby drogę do komunii eucharystycznej - może być dostępne jedynie dla tych, którzy żałując, że naruszyli znak Przymierza i wierności Chrystusowi, są szczerze gotowi na taką formę życia, która nie stoi w sprzeczności z nierozerwalnością małżeństwa. Oznacza to konkretnie, że gdy mężczyzna i kobieta, którzy dla ważnych powodów - jak na przykład wychowanie dzieci - nie mogąc uczynić zadość obowiązkowi rozstania się, postanawiają żyć w petnej wstrzemięźliwości, czyli powstrzymywać się od aktów, które przysługuja jedynie małżonkom ${ }^{46}$.

Nauczanie to uzupełnia papież Franciszek. Wskazuje on, że w pewnych wypadkach współżycie seksualne bez ślubu nie musi być równoznaczne z grzechem śmiertelnym. Wynika to $\mathrm{z}$ różnych uwarunkowań i okoliczności łagodzących i podlega rozeznaniu Kościoła ${ }^{47}$.

\section{Zakończenie}

Już od lat czterdziestych xx wieku mówi się o utracie poczucia grzechu przez człowieka, nie tylko przez ogół ludzi, ale także przez wiernych Kościoła katolickiego. Również wiek xx I charakteryzują takie zjawiska jak wypaczenie, zaćmienie, martwota i znieczulenie ludzkich sumieńn ${ }^{48}$. Ten proces nie słabnie, ale wydaje się przybierać na sile. Jeśli przyjęcie Ciała Chrystusa w grzechu śmiertelnym jest kolejnym grzechem śmiertelnym, co do czego Duns Szkot nie

\footnotetext{
45 FC 84 .

46 Tamże.

47 Por. Franciszek, adhort. apost. Amoris laetitia (19 marca 2016), 301

${ }^{48}$ Por. Jan Paweł II, adhort. apost. Reconciliatio et paenitentia (2 grudnia 1984), 18.
} 
ma wątpliwości, to wydanie pozwolenia na taką praktykę nie leży w gestii Kościoła ${ }^{49}$. Zanikowi poczucia grzechu i świadomości jego destrukcyjnych skutków powinno przeciwstawiać się nauczanie teologów, co byłoby kontynuacją chlubnej tradycji świętych doktorów Kościoła i właściwą realizacją misji teologa $\mathrm{w}$ Kościele $^{50}$. Zgodnie z nauczaniem papieża Franciszka ta wierność doktrynie nie może być jednak równoznaczna $\mathrm{z}$ „kamienowaniem” grzeszników.

Droga sakramentalna nie jest jedynym sposobem zbawienia człowieka. Odmówienie komunii świętej nie jest brakiem miłosierdzia, ale może okazać się właśnie jego aktem, pozwala bowiem osobie zrozumieć prawdę o stanie jej duszy, co może w dalszej perspektywie umożliwić jej zerwanie z grzechem czy zwrócenie się do Boga z pokorną modlitwą celnika (por. Łk 8, 10-14). Ostatecznie celem życia człowieka nie jest przyjmowanie komunii, ale zbawienie wieczne i osiągnięcie Królestwa Bożego, o czym przekonuje w swoich pismach bł. Jan Duns Szkot.

\section{ABSTRAKT}

\section{Błogosławiony Jan Duns Szkot o możliwości przyjęcia komunii świętej w stanie grzechu śmiertelnego. Analiza w kontekście współczesnych dyskusji teologiczno-dyscyplinarnych}

Dyskusja w Kościele nad dopuszczeniem osób rozwiedzionych, żyjących w powtórnych związkach do komunii świętej jest częścią szerszej debaty nad możliwością przyjmowania komunii w grzechu śmiertelnym. Na ten temat wypowiadali się teologowie w różnych wiekach. Genialny franciszkański teolog bł. Jan Duns Szkot rozumie takie działanie jako następny grzech śmiertelny. Jednocześnie respektuje osąd dokonany przez prawe sumienie, czy taki grzech przed przyjęciem komunii miał miejsce. Pozwala on także na przyjęcie komunii w celu uniknięcia zgorszenia wiernych, pod warunkiem mocnego postanowienia wyznania grzechu w sakramencie pojednania tak szybko,

49 KPK, kan. 915: „Do komunii świętej nie należy dopuszczać ekskomunikowanych lub podlegających interdyktowi, po wymierzeniu lub deklaracji kary, jak również innych osób trwających z uporem w jawnym grzechu ciężkim”.

50 DV 21: „Żywy Urząd Nauczycielski Kościoła i teologia, mimo różnych darów i funkcji, mają ostatecznie ten sam cel: zachowanie Ludu Bożego w wyzwalającej prawdzie i uczynienie go w ten sposób świattem narodów”.

TD 39: „Z jednej strony Urząd Nauczycielski potrzebuje teologii, aby w swoich wystąpieniach dać dowód nie tylko autorytetu doktrynalnego, ale także kompetencji teologicznej i zdolności oceny krytycznej, toteż teologowie powinni być wzywani do udzielenia wsparcia Urzędowi Nauczycielskiemu w przygotowywaniu i formułowaniu jego wypowiedzi”. 
jak będzie to możliwe. Ten wyjątek nie dotyczy wiernych, którzy nie mają mocnego postanowienia zerwania z grzechem. Autor artykułu wskazuje, że dopuszczenie do przyjmowania komunii osób w takim stanie będzie szkodą dla ich życia duchowego i przyczyni się do większej utraty poczucia grzechu wśród współczesnych katolików.

\section{SŁOWA KLUCzOWE}

komunia święta, bł. Jan Duns Szkot, sakrament pojednania, dyscyplina sakramentalna, związki niesakramentalne

\section{Abstract}

Blessed John Duns Scotus on the possibility of reception of the Holy Communion in the state of mortal sin. Analysis in the context of contemporary theological-disciplinary discussions

The discussion in the Church on admition of divorced and remarried to the Holy Communion is a part of a broader debate on the possibility of reception of the Holy Communion in the state of mortal sin. Theologians of various periods in the history of the Church, gave their opinions on that subject. A genius Franciscan scholastic theologian bl. John Duns Scotus considers such an action as a further mortal sin. At the same time he respects the judgement made by an upright conscience of such a prior sin and allows reception of the Holy Communion in order to avoid depravity of the faithful, on condition of a firm resolution of confessing the sin in the sacrament of Reconciliation as soon as possible. These exceptions cannot refer to people who do not have a firm resolution of rejecting the sin. The author of the article reflects that allowing the reception of the Holy Communion by such people would be with damage to their spiritual life and would contribute to a greater loss of the sense of $\sin$ among contemporary Catholics.

\section{KEYWORDS}

Holy Communion, Bl. John Duns Scotus, Sacrament of Reconciliation, sacramental discipline, non-sacramental unions

\section{BiBLIOGRAFIA}

Augustyn, Homilie na Ewangelie i Pierwszy List św. Jana, t. 1, przeł. W. Szołdrski, W. Kania, Warszawa 1977.

Concilium Toletanum XII, [w:] Collectio maxima conciliorum omnium Hispaniae et novi orbis, epistolarumque decretalium celebriorum necnon plurium monu- 
mentorum veterum ad illam spectantium, vol. 4, eds. J. Sáenz de Aguirre, G. Catalani, Romae 1755, s. 262-278.

Franciszek, Adhortacja apostolska Amoris laetitia. O miłości w rodzinie, 19 marca 2016, Częstochowa 2016.

Gennadius Scholasticus, De Ecclesiasticis dogmatibus, [w:] Patrologiae Cursus Completus. Series Latina, vol. 58, ed. J. P. Migne, Parisiis 1862, k. 979-10oo.

Gratianus, Dekretum Gratiani. Patrologiae Cursus Completus. Series Latina, vol. 187, ed. J. P. Migne, Parisiis 1855.

Jan Duns Szkot, Ordinatio, Civitas Vaticana 2010, lb. Iv, dist. 9, q. 1, 5 (Opera omnia, vol. 12).

Joannes Paulus PP. II, Adhortatio apostolica Familiaris consortio de Familiae Christianae muneribus in mundo huius temporis, 22 listopada 1981, AAS 74 (1982), s. 81-191; tekst polski: Jan Paweł II, Adhortacja apostolska Familiaris consortio, Wrocław 1998.

Joannes Paulus PP. II, Adhortatio apostolica Reconciliatio et paenitentia de reconciliatione et paenitentia in hodierno Ecclesiae munere, 2 grudnia 1984, AAS 77 (1985), s. 185-275; tekst polski: Jan Paweł II, Adhortacja apostolska Reconciliatio et paenitentia, Wrocław 1999.

Joannes Paulus PP. II, Litterae encyclicae Veritatis splendor de quibusdam quaestionibus fundamentalibus doctrinae moralis Ecclesiae, 6 sierpnia 1993, A AS 85 (1993), s. 1133-1228; tekst polski: Jan Paweł II, Encyklika Veritatis splendor, Wrocław 1994. Kaczyński E., Prawda, dobro, sumienie. Z zagadnień teologii moralnej, Warszawa 2007. Katechizm Kościoła katolickiego, Poznań 2002.

Kodeks prawa kanonicznego, Poznań 1984.

Kongregacja Nauki Wiary, Instrukcja o powołaniu teologa w Kościele Donum veritatis, [w:] W trosce o petnię wiary. Dokumenty Kongregacji Nauki Wiary, t. 1, red. J. Królikowski, Z. Zimowski, Tarnów 1995, s. 353-369.

Kongregacja Nauki Wiary, List do biskupów Kościoła katolickiego na temat przyjmowania komunii św. przez wiernych rozwiedzionych żyjących w nowych związkach (14 września 1994), „L'Osservatore Romano” (wyd. polskie) 163 (1994) nr 11, s. 49-51.

Międzynarodowa Komisja Teologiczna, Teologia dzisiaj. Perspektywy, zasady i kryteria, Kraków 2012.

Petrus Lombardus, Libri IV sententiarum, vol. 2, Florentia 1916.

Raymundus de Pennaforte, Decretales D. Gregorii Papae Ix. Suae integritati vna cum glossis restitutae, Romae 1582.

Sobór Laterański Iv, Konstytucja Omnis utriusque sexus, [w:] Dokumenty soborów powszechnych, t. 2, red. A. Baron, H. Pietras, Kraków 2007, s. 258-261. 
Sobór Trydencki, Nauka o świętych sakramentach pokuty i ostatniego namaszczenia, [w:] Dokumenty soborów powszechnych, t. 4, red. A. Baron, H. Pietras, Kraków 2004, s. 483-513.

Tomasz z Akwinu, Suma teologiczna. Eucharystia, t. 28, przeł. S. Piotrowicz, Londyn 1974.

Williams T., Introduction. The Life and Works of John Duns the Scot, [w:] The Cambridge Companion to Duns Scotus, ed. T. Williams, Cambridge 2003, s. 1-14. 